\title{
Strengthening road construction to support fishermen community activities in Belawan Fisherman village
}

\author{
M.A.P. Handana ${ }^{1 *}$, S. Syahrizal ${ }^{1}$, R. Karolina ${ }^{1}$, R.I. Siregar ${ }^{1}$, R A.M.Kamal ${ }^{1}$, \\ ${ }^{1}$ Department of Civil Engineering, Faculty of Engineering, University of North Sumatra, \\ Medan, Indonesia \\ *Email: agung.putra@usu.ac.id
}

\begin{abstract}
Most of people in Belawan Fishermen's Village area are still constrained by access roads that are feasible to go through in carrying out their activities. Limited funds and lack of equitable development and assistance from the surrounding communities to build decent roads such as concrete footpaths, make them survive using roads made of non-structural wooden planks. Road construction that is not in accordance with the standards of road construction on the seafront makes them have to repeatedly replace the wooden planks because it is easily weathered and not strong enough to withstand heavy loads. In this Community Service Program, concrete trails will be made with the aim of creating a long road life, so that the surrounding community has no difficulty with road access. The method that will be used in making concrete roads is adjusted to the technical standards of concrete roads. Roads made with certain concrete quality based on laboratory test results, the pile foundation used is the pipe foundation, while the dimensions of the concrete road floor are adjusted to the technical standards of the concrete road.
\end{abstract}

Keyword: Belawan, concrete, construction, road, wood

\section{INTRODUCTION}

Belawan fishing village is the location of the community where the majority of people live as fishermen. Local people form small groups of fishermen and live on the beach and utilize the coastline as a place to live and live as fishermen. Aside from being a fisherman, the local community also works as a fish farmer.

The road condition which was originally only a semi-permanent road was in the form of non-structured woods, so that the community had to periodically replace the wood that had been separated from the pole and weathered. Of course this will take a lot of time and money.

The development of settlements that utilize the coastline as a place of residence certainly requires different infrastructure from settlements in urban areas, among others in terms of the form of houses and roads. Local people live in houses with poles and only have footpaths to connect one house to another. The availability of proper road infrastructure for the community of Belawan Fisherman Village is highly anticipated so that their activities and activities run smoothly.

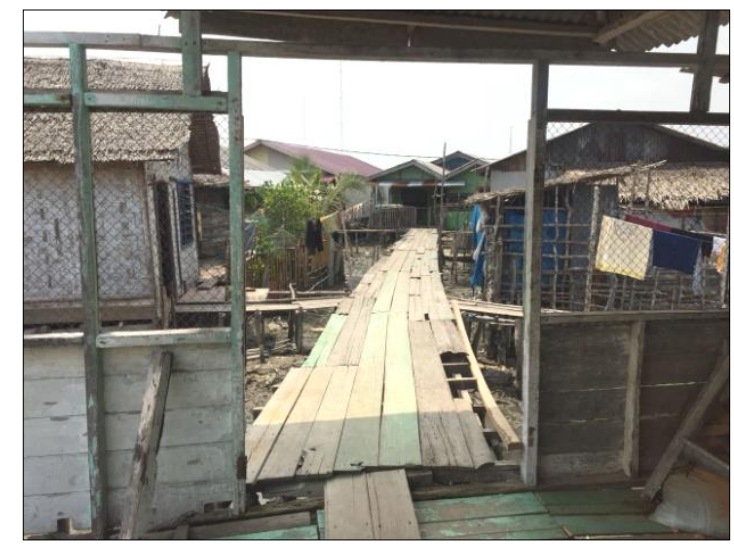


Figure 1. The condition of the semi-permanent road of Belawan Fisherman Village.

The picture above is a simple dock condition that is utilized by the local community to tether their boats in their activities as fishermen. In addition, the place is one of the infrastructures to increase and reduce passenger boats. Non-structural woods that are used as foundation piles and pier floor plates are vulnerable to weathering and risk to local communities for activities.

The lack of infrastructure to tether ships and infrastructure used by passengers to wait for the ferry to arrive will certainly make it difficult for the local community to prosper in economic and transportation issues.

Foundations of road structure that are only made of pieces of wood from small trees and not suitable to be used as road foundations. Everyday people have to go through roads like this, of course there are risks that arise as the road becomes damaged if a heavy load is passed.

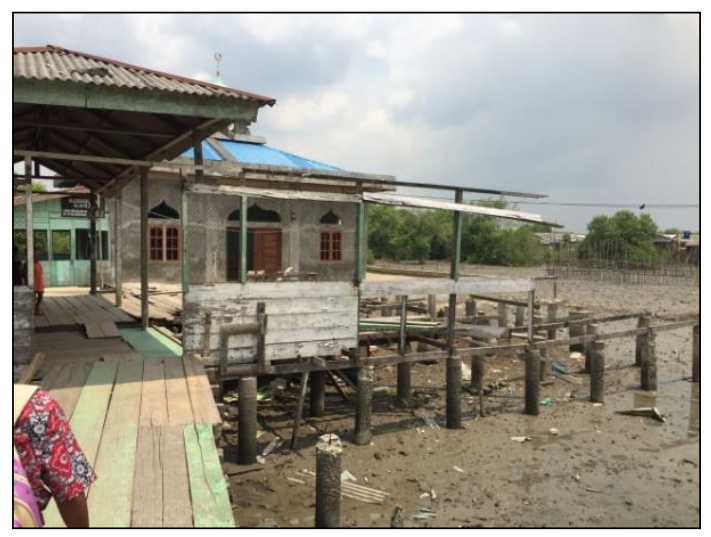

Figure 2. The road that the Belawan Fisherman Village residents go through in their activities as fishermen and to carry out other activities.

The main things and priorities that are the problem for the village Fishermen who are service partners are semi-permanent roads from non-structural wood materials that are not feasible to go through and have a short road life so there is a need for road repairs or road structure changes to structural materials that have longer road life. Road foundations that are only made of pieces of wood from small trees and not suitable to be used as road foundations.

The road has a short road life so there is a need to repair roads or change road structures to structural materials that have a longer road life. Road foundations and pier floor plates that are only made of pieces of non-structural wood from small trees and not suitable to be used as road foundation.

\section{METHODS}

Location of study of strengthening road construction to support fishermen community activities in belawan fisherman village 


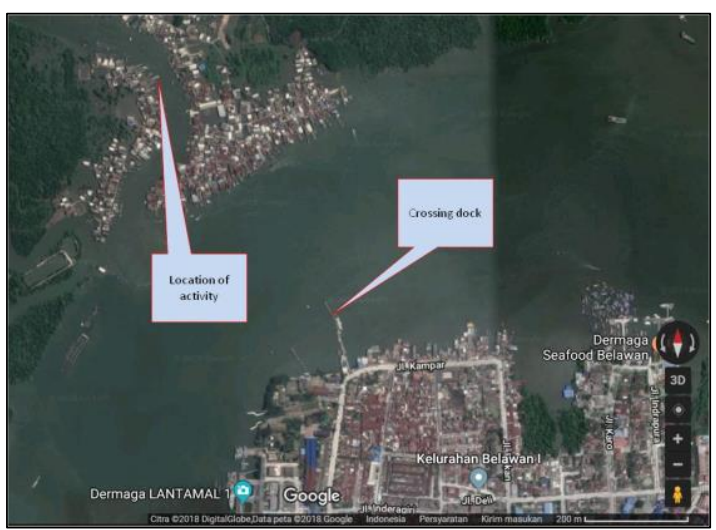

Figure 3. Location of study

In the construction of concrete roads in Belawan Fisherman Village, before carrying out concrete road works there are several stages of analysis to determine the dimensions of the concrete road to be made. Stages of concrete road implementation activities from holding the analysis until the work in the field are as follows: 1) Literature study, the purpose is to determine the method, the correct way of working and in accordance with the problems in the partner location; 2) Phase of analysis, at this stage what is done is to design the dimensions of the road; 3) Preparation of tools and materials, the purpose is to prepare the equipment and materials needed in the road construction of concrete. Tools and materials are conditioned according to the available study location; 4) Making the foundation or supporting pillar of the building, the initial stages of construction after the preparation of tools and materials (material) is to build a pile foundation that is adjusted to the study location. The foundation used is only pipe foundation; 5) Installation of formwork, installation of formwork / mall as concrete road mold to be made; 6) Casting the road, after being installed formwork then casting.

One thing that is unique about this concrete road work is the storage of materials placed under the houses of residents, especially the sand and gravel. The material is positioned in the water just below the people's house.

The concrete road is a rigid pavement which is a type of road pavement that uses concrete as the main material for the pavement. In the seafront building, pile foundation is used for the concrete road. In sand soil, the pile foundation is intended to compact the sand so that the capacity of the soil can increase and be able to support the foundation of the building whose surface is easily eroded by water.

Corrosion on concrete can be detrimental to us as users of the building structure, in addition to shortening the usage, the maintenance costs or repairs are often greater than the value of the building. The following is a recommendation to get a long-lasting concrete structure in the marine environment: 1) The use of basic concrete materials (such as aggregates) and good quality concrete using second type cement; 2) Selection of corrosion-resistant material with an existing environment, preventing contact between iron and the environment, such as painting or coating with non-corroded material, besides that the type and quality of concrete greatly affect the corrosion resistance in concrete; 3) Conveying a concrete sheath with a thickness of the same as appropriate with the environmental conditions that you are facing, or less environmentally, the more blanket can be needed at least $7 \mathrm{~cm}$ thickness of concrete the inner concrete reinforcement. The concept of the pile foundation on the concrete road on the seafront is the same as the concept of the pier pile foundation which is a building with reinforced concrete structures that are located rather protruding into the water. The dead load received by the foundation on the dock structure is smaller compared to other loads that work such as wind loads and wave loads. The wind load and wave load have a tendency to move horizontally. 


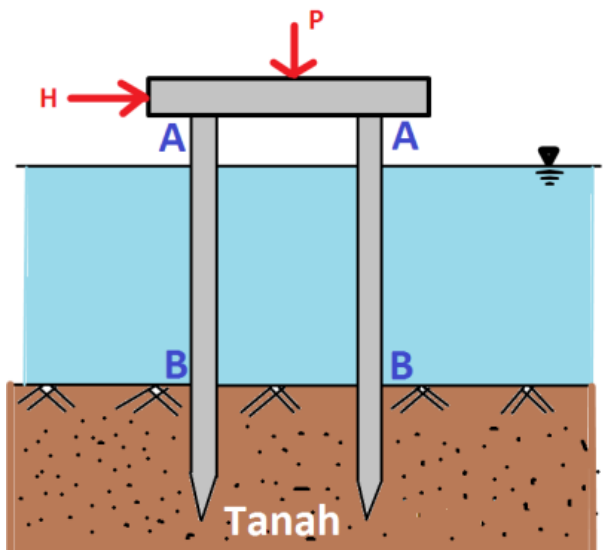

Figure 4. The concept of concrete pile foundation on the concrete road that will be applied to the path of Belawan Fisherman Village

The stages of making concrete roads can be explained through the following procedures tailored to the field work, namely: 1) Prepare the materials needed for the work in the field according to the planned concrete road; 2) Preparation of land by installing bowplank to determine the points of the foundation pole; 3) Pair the pile (pvc pipe as a casing) at the specified points; 4) Put reinforcement on the pile; 5) Prepare concrete mixture materials; 6) Site concrete mixes using molen machines; 7) Perform casting for all of the pile; 8) Install the mall / mold using plywood on the sides of the floor plate to be concrete; 9) Assembling and installing iron / reinforcement for concrete road floor plates; 10) Make a pile reinforcement connection with floor plate reinforcement; 11) Re-prepare concrete mix materials; 12) Site mix concrete using molen machines; 13) Do casting for all the concrete road floor plates; 14) Wait up to 14 days after casting is done; 15) Then open the mall / concrete mold; 16) Finish and the road is ready for use.

The following is a picture of the initial design for the concrete road that was applied at the location of the community service activities in Belawan Fisherman Village. The picture below is the initial condition when the concrete road construction has not been made at that location.

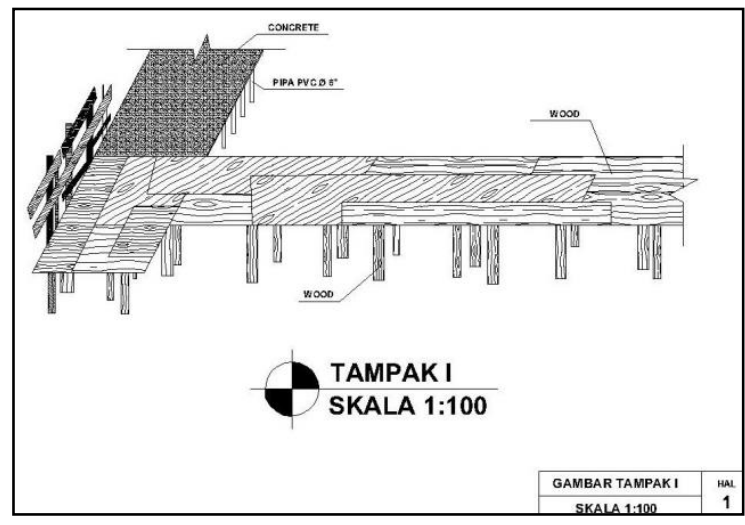

Figure 5. The first condition of the road before being made concrete road Belawan Fisherman Village.

While the following picture is a design made for the concrete road of Belawan Fishermen's village. 


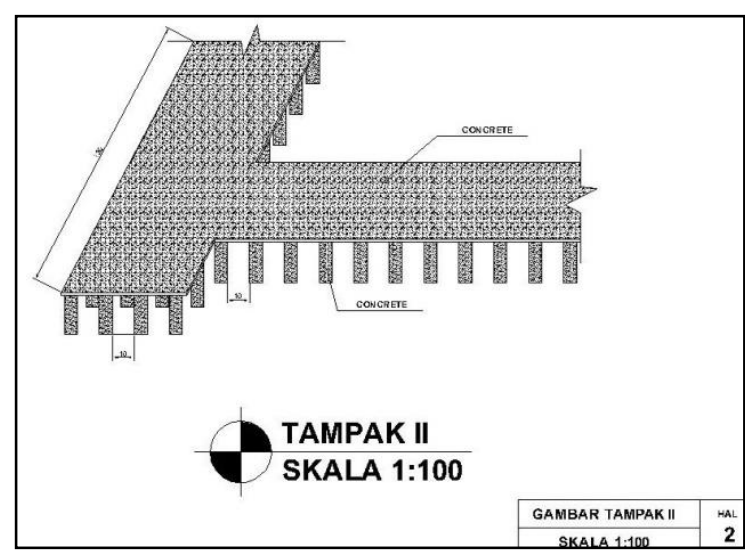

Figure 6. Design of concrete plans that will be made in the reading cottage of Belawan Fisherman Village.

The activity of making concrete pile foundations using concrete material as the main material used. The concrete used consists of the following materials: 1) Portland Cement, is an important bonding material and is widely used in development; 2) Sand (fine aggregate), sand used in the manufacture of lightweight concrete is sand that passes the sieve according to ASTM E 11-70 standards whose diameter is smaller than $5 \mathrm{~mm}$; 3) Gravel (coarse aggregate) is a small rock, usually granite that is broken. The size of the gravel that is always used is between $2 \mathrm{~mm}$ and 75 $\mathrm{mm}$; 4) Water, is one of the ingredients needed to mix concrete to trigger the chemical process of cement, wet the aggregate and provide ease of work; 5) PVC pipes, used for concrete molding on concrete road piles. Polyvinyl chloride (PVC) is a pipe made of plastic and some other vinyl combinations; 6) Concrete reinforcement iron, used is $10 \mathrm{~mm}$ in size; 7) Molen machine, Molen's function is to make a stir, both for pair and plastering purposes, sand and cement are mixed evenly according to certain mixtures which will produce a concrete mixture. The molen machine consists of a stirring tube, motor, molen wheel, frame, tube inverting wheel, and lock

\section{RESULT AND DISCUSSION}

All stages are worked out at the service location by the dedication team and students who are included in the activity. In addition activities are assisted by the local community for the process of carrying out the construction of concrete roads.

The series of activities lasted for several weeks which were done by the craftsmen and supervised by the team and the local community. Collaboration with fellow team members and the community helps to complete roadwork quickly so that the community can enjoy it. The following is documentation of the work in the field 


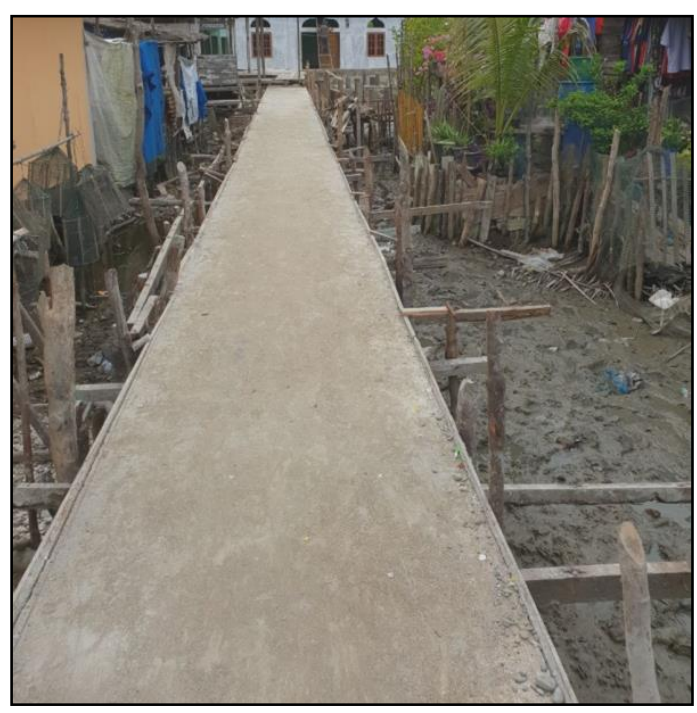

Figure 7. The condition of concrete road work activities is the location of community service in Belawan Fishermen's Village

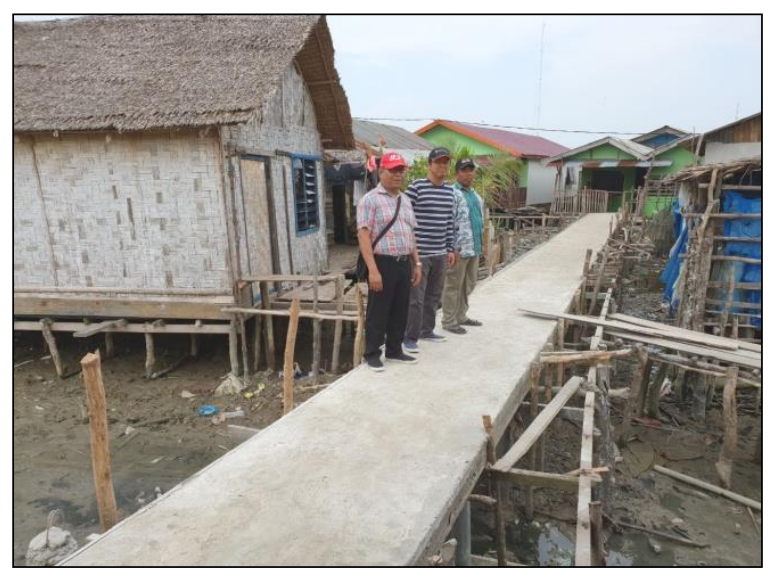

Figure 8. Team leader and team members at the location of the service activities

Based on the service activities that have been carried out in accordance with the method of road works and with limited costs, the length of the road can be carried out as long as 35 meters and the thickness of the concrete road is $15 \mathrm{~cm}$. The following picture is a condition after completion of the activity 


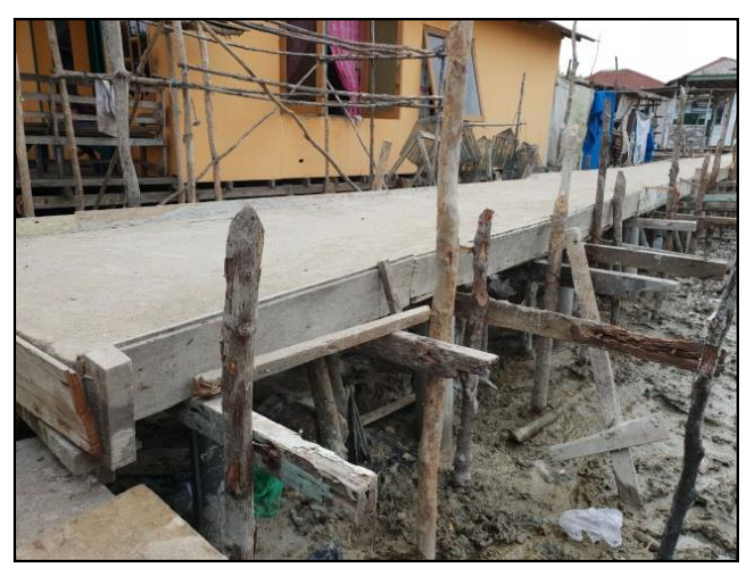

Figure 9. The condition of concrete road work activities is the location of community service in Belawan Fishermen's Village

\section{CONCLUSION}

The conclusions of the concrete road construction activities are as follows: 1) The concrete road made to support community activities in Belawan Fisherman Village is 35 meters in length; 2) The road constructed has a concrete plate with a thickness of $15 \mathrm{~cm}$; 3) The Community Service Program activities carried out by the dedication team can be used directly by the people of Kampung Nelayan, Belawan to act as fishermen; 4) These activities can facilitate the achievement of the level of community economic growth.

The suggestions given for this activity include: 1) The dedication team hopes that in the future the road built for the benefit of community fishing activities can be even longer in size; 2) The Service Team really expects maximum benefits for the community of Belawan Fishermen Village to increase access to their work

\section{ACKNOWLEDGMENTS}

A big thank to the Community Service Agency (LPM), Universitas Sumatera Utara, for the funding this community service activity which was sourced from BPPTN 2018 funds, Universitas Sumatera Utara..

\section{REFERENCES}

Abdullah Yudith, 2008, Pengaruh Zat Aditif pada Pembuatan Bata Beton Ringan, FT UI, Jakarta.

ASTM, 1997. ASTM Annual Book of ASTM Standards Section 4 Volume 04.02. ASTM 100 West Conshohocken, PA.

ASTM C 567 , Unit Weight of Structural Lightweight Concrete, American Standard for Testing Materials.

ASTM C 796 - 87 a,Table 1, Foaming Agents for Usse in Producing Cellular Concrete Using Preformed Foam, American Standard for Testing Materials.

ASTM C 869-91, Standard specification for foaming agents used in making preformed foam for cellular concrete, American Standard for Testing Materials. 
Handana et.al Strengthening road construction

Lukito Prasetyo, 2010, Maksimasi Kuat Tekan Beton, Malang.

Mandala Siliwangi, et al, 2014. Perancangan pondasi tiang pancang dermaga packing plant Banjarmasin-Kalimantan Selatan, Jurnal Karya Teknik Sipil, Universiats Diponegoro.

Nugraha, Paul, dan Antoni, 2007. Teknologi Beton, Yogyakarta, Penerbit Andi.

Suwandi, 2012. Perencanaan pondasi tiang pancang pipa baja pada pembangunan dermaga Melak. Jurnal Teknik Sipil dan Arsitektur, Samarinda.

Tiurma Simbolon, Pascasarjana USU, 2009, Pembuatan dan Karakterisasi Bata Beton Ringan, Medan.

Tri Mulyono, 2005, Teknologi Beton, Yogyakarta, Penerbit Andi. 